\title{
The Effect of Comprehensive Written Corrective Feedback on EFL Learners' Written Syntactic Accuracy
}

Mohammadreza Valizadeh*

Department of Translation and Interpretation (English), Faculty of Humanities, Cappadocia University, Cappadocia, Turkey

Corresponding Author: Mohammadreza Valizadeh, E-mail: mrvalizadeh2015@gmail.com

\section{ARTICLE INFO}

Article history

Received: October 20, 2019

Accepted: December 18, 2019

Published: February 29, 2020

Volume: 11 Issue: 1

Advance access: February 2020

Conflicts of interest: None

Funding: None

\author{
Key words: \\ Comprehensive/Unfocused \\ Corrective Feedback, \\ Written Corrective Feedback, \\ Direct Corrective Feedback, \\ Metalinguistic Explanation, \\ Syntactic Accuracy
}

\begin{abstract}
This quasi-experimental study, using a pretest-treatment-posttest-delayed posttest design, investigated the effects of two comprehensive corrective feedback strategies: direct corrective feedback (DCF), and metalinguistic explanation (ME) on L2 learners' written syntactic accuracy. The participants were 90 Turkish EFL learners. After ensuring their homogeneity in terms of L2 proficiency using Oxford Quick Placement Test, they were assigned to three groups: DCF, ME, and No Feedback (NF). The treatment/control period lasted for five weeks, during which the experimental groups wrote an argumentative essay in class, received the unfocused feedback, and revised their corrected text. The participants in the NF group were provided with feedback only on content, orthography, and organization, but not on grammatical errors. Results of the posttests and delayed-posttests (after a two-week interval) revealed that both experimental groups significantly outperformed the NF group; however, no statistically significant difference was found between the DCF and ME groups. Pedagogical implications are discussed in the paper.
\end{abstract}

\section{INTRODUCTION}

Output production is a valuable source for the acquisition of second language (L2) forms because it can promote noticing, which is an essential condition for L2 acquisition (Schmidt, 1990, 1993); through producing output, learners reflect on their metalinguistic knowledge and test hypotheses about their L2 grammar (Swain, 1985, 1995). Nevertheless, Swain (1991), Han (2002), and Havranek (2002) noted that for L2 linguistic development, output production needs to be accompanied by corrective feedback (CF). As a matter of fact, adult L2 learning requires some degree of negative input (VanPatten, 2015) in the form of CF (Ellis \& Shintani, 2014) to guide learners to notice the gap between the ideal and their existing knowledge, recognize what is lacking or wrong in their production and modify their interlanguage (Gass \& Varonis, 2004; Schmidt, 1995, 2001), possibly as a result of the established explicit knowledge (DeKeyser, 2015).

Despite the mentioned point, Truscott (1996) argued CF is not only ineffective but harmful; thus, providing it must be stopped. His argument yielded several counter responses from a number of researchers (Bruton, 2009a, 2010; Ferris, 1999, 2004, 2006; Lyster, Lightbown, \& Spada, 1999). Whereas some of the early studies, which explored the usefulness of Written Corrective Feedback (WCF) versus no feedback indicated no significant advantage for feedback (see e.g., Kepner, 1991; Polio, Fleck, \& Leder, 1998; Semke, 1984), a large number of the studies which explored different types of feedback concluded that their explored type of WCF was beneficial (see e.g., Benson \& DeKeyser, 2019; Bitchener, 2008; Bitchener, East, \& Cartner, 2010; Bitchener \& Knoch, 2008, 2009, 2010a; Bitchener, Young, \& Cameron, 2005; Bonilla López, Van Steendam, Speelman, \& Buyse, 2018; Chandler, 2003; Ellis, Sheen, Murakami, \& Takashima, 2008; Frear \& Chiu, 2015; Sheen, 2007, 2010a; Sheen, Wright, \& Moldawa, 2009; Van Beuningen, De Jong, $\&$ Kuiken, 2008, 2012). However, recently, Karim and Nassaji (2018), who explored direct vs. indirect comprehensive feedback, reported only the participants' revisions improved significantly, but the students' accuracy improvements on new written text after receiving direct and underlining + metalinguistic comprehensive feedback types were not significant.

Although the positive effects of the focused feedback have been proved in several studies (see e.g., Bitchener, 2008; Bitchener et al., 2010; Bitchener \& Knoch, 2008, 2009, 2010a; Bitchener et al., 2005; Sheen, 2007, 2010a; Sheen et al., 2009) "evidence on the language learning 
potential of unfocused $\mathrm{CF}$, which involves comprehensive correction of every error in students' writing, is scarce" (Van Beuningen et al., 2012, p. 5). To date, the studies, which explored the effect of comprehensive/unfocused CF on L2 students' written accuracy, found different and controversial results.

As literature presents, from the late $80 \mathrm{~s}$ to the $2000 \mathrm{~s}$, some scholars explored the effects of various comprehensive WCF methods, including writing comments and questions without corrections, providing both positive comments and corrections, direct CF, and coded indirect CF (Semke, 1984), direct CF, coded, uncoded, and marginal feedback (Robb, Ross, \& Shortreed, 1986) error-corrections vs. message-related comments (Kepner, 1991), "discrete item attention to form and holistic feedback on meaning" (Sheppard, 1992, p. 103) direct vs. indirect CF (Chandler, 2003; Van Beuningen et al., 2008) as well as indirect CF (Truscott \& Hsu, 2008). Although some of the mentioned studies did not find positive effects for comprehensive CF (Kepner, 1991; Semke, 1984), some of the others indicated promising results (Chandler, 2003; Robb et al., 1986; Sheppard, 1992). Truscott and Hsu (2008) found that comprehensive CF enabled their learners to improve the accuracy of their texts during revision, but it did not lead to accuracy gains when writing a new text. Van Beuningen et al. (2008) showed that both direct and indirect comprehensive $\mathrm{CF}$ were effective in the short term, but only direct CF was significantly effective in the long term.

Due to the fact that the mentioned early studies proved to have some shortcomings, their findings cannot be accepted as clear evidence for the presence or absence of an effect for comprehensive WCF. For instance, Semke's (1984) study suffered from not having a real control group and an incentive because one of the groups in that study "worried about losing points, while the other three groups probably needed to write less for fear of making too many mistakes." (Guénette, 2007, p. 50). The absence of a no-correction control group can be the shortcoming of Robb et al.'s (1986) and Sheppard's (1992) studies, according to Van Beuningen et al. (2012). Though Kepner (1991) did not find positive effects, (Ferris, 2003, 2004) suggested that there was at least weak evidence of a beneficial effect for written CF because the correction group made fewer errors. Moreover, Ferris (2003) found a serious problem with the design of Kepner's study. Kepner did not measure the initial accuracy levels of the two groups and just compared the sixth set of journal entries. Therefore, as Ferris (2003) stated, there is no way of knowing whether the two groups of learners had the same initial level of accuracy. Further, as Ferris (2003) found, "there was no control for the length of the journal entries (which were written outside class), a variable that could affect both error and proposition counts" Ferris (2003, p. 60). Moreover, Bitchener and Ferris (2012) argued that in Kepner's study, the collected students' journal entries as their writing were neither revised nor individually graded which received feedback consisted of that. Thus, it is unlikely that the learners in Kepner's study were paying close attention to the received feedback and if the students had not paid attention to feed- back, the findings would not be used as evidence that such feedback would be ineffective (Bitchener \& Ferris 2012). As a result, it is crucial to interpret the results of the study with caution because it is not clear evidence of the ineffectiveness of comprehensive WCF. Considering Truscott and Hsu's (2008) study, (Bruton, 2009a) noted that the participants in their study had very few errors during the pretest in the beginning of the study, so this could have affected the findings. As for Van Beuningen et al.'s (2008) investigation, Bitchener and Ferris (2012) stated that it is not clear whether Van Beuningen et al. (2008) controlled for additional linguistic input between giving feedback and the one-week delay in giving the immediate post-test, and whether the self-correction group was a real control group given that the learners' attention was focused on accuracy when doing the self-correction and given that this occurred before the immediate post-test, one week later.

More recently, in the 2010s, some scholars also investigated and compared the effects of different comprehensive WCF methods on improving the accuracy of L2 learners' written texts, including direct vs. indirect CF (Karim \& Nassaji, 2018; Van Beuningen et al., 2012) as well as DCF and metalinguistic codes, both for grammatical and non-grammatical errors (Bonilla López et al., 2018). Van Beuningen et al. (2012) revealed that both direct and indirect comprehensive CF improved the written accuracy. Nevertheless, as for the effect of feedback types on types of errors, it was found that only DCF led to grammatical accuracy improvements in new writing, whereas indirect $\mathrm{CF}$ was advantageous for the non-grammatical accuracy gains. Bonilla López et al. (2018) indicated that DCF and codes were beneficial for improving learners' grammatical and non-grammatical accuracy during text revision; however, a long-term advantage (i.e., 4 weeks after feedback provision) was only found for direct corrections. Finally, Karim and Nassaji (2018) who explored the short-term and delayed effects (after a two-week interval) of comprehensive direct $\mathrm{CF}$ and two types of indirect $\mathrm{CF}$, involving underlining only and the other underlining+metalinguistic cues on L2 learners' revision accuracy and writing text found that all the three feedback types significantly improved the revised texts. However, the accuracy improvements on new writing text, which was found for DCF and underlining + metalinguistic feedback types were non-significant.

As Bitchener and Ferris (2012) stated "the role of written CF in L2 development is an exciting and dynamic area of investigation, and, as such, is likely to continue engaging the energy and insights of established and emerging scholars." (p. 27). Given the scarcity of research on unfocused CF (Van Beuningen et al., 2012, p. 5) and the controversial findings of the previous studies, this study investigated the effects of two unfocused WCF strategies: direct corrective feedback (DCF), and metalinguistic explanation (ME) on L2 learners' written syntactic accuracy (i.e., producing syntactic error-free texts) in the short and long term. DCF consists of an indication of the error and provision of the corresponding correct L2 form (Ellis, 2009); however, via ME, "the teacher numbers errors in text and writes a grammatical description 
for each numbered error at the bottom of the text" (Ellis 2009, p. 98) or on a separate paper, which are attached to the student's text.

This study selected unfocused feedback on accuracy because it is the most widely used type of feedback by teachers (Ferris, 2006; Guénette, 2012; Lee, 2004, 2008; Van Beuningen, 2010); thus, it is more ecologically valid than the focused feedback (Ferris, 2010). The unfocused/comprehensive feedback is also concerned with the writing as a whole instead of the writing as a way to practice grammar (Bruton, 2009b; Van Beuningen, 2010), which was the aim in this study. Therefore, the comprehensive/unfocused feedback serves the need for more authentic CF methodologies, focusing "on the accurate production of all aspects of writing, simultaneously" (Hartshorn et al., 2010). Further, when learners commit a range of written errors, "a limited $\mathrm{CF}$ focus does not address the need to individualize feedback according to students' different strengths and weaknesses" (Ferris, 2010, p. 192). Moreover, studies on the unfocused WCF have been scarce (Van Beuningen et al., 2012) and the results available about the effectiveness of providing learners with unfocused WCF are conflicting more evidence is "required on the relative benefits of unfocused feedback" (Bitchener \& Ferris, 2012, p. 57). Further, as the participants in this study were the upper-intermediate ones, unfocused WCF could be useful for them (Bitchener \& Ferris, 2012).

Among the WCF strategies, particularly DCF and ME were selected to be compared with each other as well as with 'no feedback' condition because via DCF, the learners are provided with adequate information to fix complex linguistic errors, such as the syntactic ones, thereby the learners will be able to instantly internalize the correct form (Chandler, 2003). Additionally, DCF is more likely to facilitate learning in case the learners' level of (meta)linguistic competence is not high to be able to self-correct their errors (Shintani \& Ellis, 2013). DCF also reduces the cognitive load of the learners and require less mental effort (Bonilla López et al., 2018). Consequently, because in this study, the unfocused/ comprehensive feedback was selected and all the learners' syntactic errors were corrected, the DCF was used to maximize the potential effect of the CF.

Regarding the ME, although the comprehensive/unfocused feedback was provided and also the learners were not provided with the correct form, they were provided with explicit comments on their errors by provision of the grammatical description (Ellis, 2009) as it is argued that the ME causes the students to engage in deeper level of processing due to the fact that they need to use the ME to correct their own errors (Shintani \& Ellis, 2013). Because the participants in the present study were the upper-intermediate ones, it was assumed that they were able to use the ME to identify and self-correct their own errors.

In short, the study addressed the following research questions:

1) Is there any significant difference between the effects of comprehensive DCF and NF (i.e., no feedback) on developing learners' syntactic accuracy in the short and long term?
2) Is there any significant difference between the effects of comprehensive ME and NF on developing learners' syntactic accuracy in the short and long term?

3) Is there any significant difference between the effects of comprehensive DCF and ME on developing learners' syntactic accuracy in the short and long term?

\section{METHOD}

\section{Participants}

The participants were 90 Turkish EFL learners between the ages of 18 to 23 , who were selected among 127 students based on the results of their Quick Placement Test (QPT). They were assigned to three 30-participant groups (50 female and 40 male). The participants took Essay Writing courses at Antalya International University in Antalya, Turkey. They all had passed the elementary and intermediate writing courses, and enrolled in upper-intermediate writing courses.

\section{Design}

The present study used a pretest-treatment/control-posttest-delayed posttest design to determine the gains in syntactic accuracy. The dependent variable in the study is the gain in syntactic accuracy. The independent variable was the comprehensive WCF type, (DCF and ME, in comparison to no feedback on syntactic errors). Additionally, the participants' English proficiency level was also considered as the control variable.

In this study, the non-random convenience sampling method was used, so it is a quasi-experimental one. As recommended by Storch (2010) the study was done in real classrooms, so the feedback was provided in the "context of an instructional program, with ecologically valid writing tasks" (Storch 2010, p. 43). Moreover, "when comparing different types of feedback, every other design parameter must remain constant" (Guénette, 2007, p. 48); therefore, the groups in this study had the same teacher; the activities, courses, and writing topics were similar as well.

It should be noted that because 127 students had enrolled in upper-intermediate writing courses, it was unlikely to exclude them from the classes, so the researcher decided to work with all the learners, but for the purpose of the research, the scores (pretest, posttest and delayed-posttest) of the students who had the necessary criterion (i.e., they were homogeneous) were considered. In other words, the students who were not homogeneous in terms of L2 proficiency and L2 writing skills were discarded from the research although they were present in classes.

\section{Instruments}

To conduct the study, the following instruments were utilized: Student biodata information questionnaire, Quick Placement Test (QPT), class writing tasks, pretest, posttest, and delayed posttest. Further, in order to assess the syntactic accuracy, and to control for the differences in text length 
written by the participants, the following formula, which had also been used by Chandler (2003), Truscott and Hsu (2008), as well as Soltanpour and Valizadeh (2018) was used: [total number of syntactic errors/total number of words] $\times 100$ to calculate a measure of errors per 100 words.

The reasons for adopting topics of the Writing Task 2 from the General Module of IELTS are as follows:

To establish the content validity, face validity, and test comparability, first, the learners' background knowledge of the writing topics was considered. The researcher managed to find writing topics with which the participants were familiar. Additionally, for the pretest to be comparable in difficulty to the posttest and delayed-posttest, as argued by Mackey and Gass (2005), the exam topics in three utilized tests and the writing tasks were of argumentative type. The participants had already learned how to write argumentative essays, so they knew about the format of the essay. Finally, as for the criterion-related validity of the test, the samples from the writing tasks of the General Module of IELTS were used, so that the utilized tests and tasks can be comparable to a standardized writing test.

\section{Data Collection Procedure}

At the outset, all the participants completed a questionnaire concerning their personal information. They were ensured that their anonymity would be guaranteed.

Frodesen and Holten (2003, as cited in Guénette, 2007) suggested that comparing the efficacy of different WCF strategies entails controlling students' English proficiency level; therefore, during the first week, to control the participants' L2 proficiency level and to ensure their homogenity, they were given the pen-and-paper version of QPT. To decide on their language level, Geranpayeh's (2003) guideline was used. Those who got scores ranging from 40 to 47 out of 60 (i.e., the upper-intermediate level), were assigned to three groups: DCF and ME, who received feedback on their grammatical errors, as well as a control group, namely NF who was provided with feedback only on content, orthography, and organization, but not on grammatical errors because as Ferris (2004) stated, it seems almost unethical to single out a group for no feedback. Afterwards, an IELTS writing task 2 test was also given to these groups as the pretest to assess their initial status of syntactic accuracy in their written texts; it was found that the students were also homogeneous in their writing ability.

The treatment/control period lasted for four more weeks. Every week the participants wrote an argumentative essay in class; then they received the specified feedback. Next, the students in experimental groups revised their corrected text as recommended by Guénette (2012), so they would be responsible for their learning. Further, revision of the written texts after receiving feedback is perhaps a beneficial and essential step toward the long-term acquisition of a specific feature (Ferris, 2004, 2010; Guénette, 2012; Sachs \& Polio, 2007). Afterwards, on the 1st session of Week 6, the posttest was given. No work on writing was done for two weeks. Finally, in the 8th week, the delayed posttest was implemented. No participant took the required tests twice; moreover, although the essay topics were different in the tests, they were the same for all three groups.

\section{DATA ANALYSIS AND RESULTS}

\section{Inter-rater Reliability}

The Cronbach alpha indices, administered to calculate the inter-rater reliability, revealed a range from a high of .97 for the delayed posttest in the NF to .92 for the posttest of the DCF group.

\section{The Normality Tests}

The assumption of normality was examined through both the graphic of histogram, and also some numerical ways as recommended by Larson-Hall (2010). The histograms indicated that the data were normally distributed. Regarding the numerical methods of assessing normality, the values of skewness and kurtosis statistics were within $+/-1$, based on Phakiti (2010); further, the outcomes of the ratio of skewedness and kurtosis over their respective standard errors were within the ranges of $+/-1.96$, based on Field (2013); therefore, the numerical tests also revealed that the data were normally distributed.

\section{Ensuring the Homogeneity of the Groups}

A one-way between-groups analysis of variance (ANOVA) was conducted to explore whether the three groups (i.e., DCF, ME, NF) were homogeneous with regard to their grammatical knowledge, as measured by the QPT. Levene's test for homogeneity of variances for QPT indicated that the assumption of homogeneity of variance was met $($ Sig. $=.87)$. Then, the ANOVA test revealed that there was not a statistically significant difference at the $\mathrm{p}<.05$ level in the grammatical knowledge score for the three groups: $\mathrm{F}(2, .87)=.03, \mathrm{p}=.97$. In conclusion, the participants in three groups were homogeneous regarding their grammatical knowledge.

Then, another ANOVA was conducted to explore whether the three groups (i.e., DCF, ME, NF) were homogeneous with regard to their syntactic accuracy, as measured by the essay writing test (i.e. pretest). Levene's test for homogeneity of variances for pretest of syntactic accuracy indicated that the significance value (Sig.) for Levene's Test was greater than .05 (Sig. $=.38)$; therefore, the assumption of homogeneity of variance was met. Next, the ANOVA for pretest of syntactic accuracy indicated that there was not a statistically significant difference at the $\mathrm{p}<.05$ level in the syntactic accuracy scores for the three groups: $F(2,87)=1.22, \mathrm{p}=.29$. In conclusion, the participants in three groups were homogeneous regarding their syntactic accuracy in their pretests.

\section{The Effect of DCF vs. NF on Developing Learners' Written Syntactic Accuracy}

To compare the mean scores of the DCF and NF groups on the posttest of syntactic accuracy, an independent t-test 
was conducted in order to explore the effect of the DCF on the improvement of the syntactic accuracy of the students' essays shortly after the administration of the treatment. It should be noted that as the formula [total number of syntactic errors/total number of words] $\times 100$ was utilized for scoring the syntactic accuracy of the essays, the fewer errors the essays included, the smaller value (mathematical quantity) they were given, so the lower values reveal the existence of fewer errors.

The assumption of homogeneity of variances was met (Levene's $\mathrm{F}=2.66, \mathrm{p}=.10>.05$ ); then, it was found that, the DCF group $(\mathrm{M}=11.05)$ outperformed the NF group $(M=12.07)$. This difference was significant $(t(58)=-14.81$; $\mathrm{p}=.000$, two-tailed); however, the magnitude of the differences in the means (mean difference $=-1.01,95 \% \mathrm{CI}:-1.15$ to -.88 was below medium based on Cohen's (1988, as cited in Pallant, 2013) (Cohen's d = 3.88).

Next, to investigate the effect of the DCF on the syntactic accuracy of the students' essays in the long term, another independent t-test was administered to compare the mean scores of the DCF and NF groups on the delayed-posttest of syntactic accuracy. Due to the fact that the assumption of homogeneity of variances was violated (Levene's $F=4.97$, $\mathrm{p}=.03<.05)$, the second row of independent t-test table, labeled "Equal variances not assumed", was consulted. Based on the results, the DCF group ( $M=10.97)$ outperformed the NF group $(M=11.96)$. This difference was significant $(\mathrm{t}(51.28)=-13.24, \mathrm{p}=.000$, two-tailed); however, the magnitude of the differences in the means (mean difference $=-.98,95 \% \mathrm{CI}:-1.13$ to -.83 was below medium based on Cohen (1988 as cited in Pallant 2013) (Cohen's d = 3.69).

\section{The Effect of ME vs. NF on Developing Learners' Written Syntactic Accuracy}

An independent t-test was run to compare the mean scores of the ME and NF groups on the posttest of syntactic accuracy in order to explore the effect of the ME on the syntactic accuracy of the essays shortly after the administration of the treatment.

The assumption of homogeneity of variances was met (Levene's $\mathrm{F}=1.13, \mathrm{p}=.29>.05$ ); then, it was revealed that the ME group $(M=10.99)$ performed significantly better than the NF group $(M=12.07)$. This difference was significant $(\mathrm{t}(58)=-15.09, \mathrm{p}=.000$, two-tailed); however, the magnitude of the differences in the means (mean difference $=-1.07$, 95\% CI: -1.22 to -.93 was below medium based on Cohen (1988 as cited in Pallant 2013) (Cohen's d = 3.96).

Then, to investigate the effect of the ME on the syntactic accuracy of the students' essays in the long term, another independent t-test was conducted to compare the mean scores of the ME and NF groups on the delayed-posttest of syntactic accuracy. Because the assumption of homogeneity of variances was violated (Levene's $F=4.69, p=.03<.05$ ), the second row of independent t-test table, labeled "Equal variances not assumed", was consulted. Based on the results, the ME group $(M=11.02)$ outperformed the NF group $(M=11.96)$. This difference was significant $(\mathrm{t}(51.53)=-12.65, \mathrm{p}=.000$, two-tailed); however, the magnitude of the differences in the means (mean difference $=-.94,95 \%$ CI: -1.09 to -.79 was below medium based on Cohen's (1988 as cited in Pallant 2013) (Cohen's d = 3.52).

\section{The Effect of DCF vs. ME on Developing Learners' Written Syntactic Accuracy}

An independent t-test was done to compare the mean scores of the DCF and ME groups on the posttest of syntactic accuracy to compare the effect of the two types of treatments on the syntactic accuracy of the essays shortly after the administration of them.

The assumption of homogeneity of variances was met (Levene's $\mathrm{F}=.41, \mathrm{p}=.52>.05$ ); then, it was found that there was not a significant difference between the DCF and $\mathrm{ME}$ (DCF: $\mathrm{M}=11.05$; $\mathrm{ME}: \mathrm{M}=10.99)$. $(\mathrm{t}(58)=1.02$, $\mathrm{p}=.31$, two-tailed); (Cohen's $\mathrm{d}=.26)$.

Then, to compare the mean scores of the DCF and ME on the improvement of the syntactic accuracy of the students' essays in the long term, another independent t-test (delayedposttest of syntactic accuracy) was run.

The assumption of homogeneity of variances was met (Levene's $\mathrm{F}=.000, \mathrm{p}=.93>.05$ ); next, it was revealed that there was not a significant difference between the DCF and ME. (DCF: $\mathrm{M}=10.97 ; \mathrm{ME}: \mathrm{M}=11.02) .(\mathrm{t}(58)=-.69, \mathrm{p}=.49$, twotailed $)=.49>.05) ;($ Cohen's $\mathrm{d}=.18)$.

\section{DISCUSSION AND CONCLUSION}

Truscott (1996, 1999, 2004, 2007, 2009, 2010) argued that CF should not be used in L2 classrooms due to the fact that correcting the grammatical mistakes would be more likely to prevent than to facilitate accuracy development. However, the findings of the present study clearly indicated that unfocused WCF is effective for improving learners' accuracy; therefore, Truscott's argument that CF has detrimental side effects is not supported by this study.

Some of the early studies did not show promising results for the WCF (e.g., Kepner, 1991; Polio et al., 1998; Semke, 1984), and recently Karim and Nassaji (2018) found that only the participants' revisions improved significantly after applying the comprehensive WCF, but the accuracy improvements on new writing text, which was found for the DCF and underlining+metalinguistic comprehensive feedback types were non-significant. On the contrary, similar to Robb et al.'s (1986), Chandler's (2003), Van Beuningen et al.'s (2008, 2012) as well as Bonilla López et al.'s (2018) findings, this study indicated that learners who received comprehensive or unfocused WCF made significantly fewer errors in newly produced texts than students who were not provided with $\mathrm{CF}$ on their errors.

Considering the goal and scope of the present study, very few studies exist to be exactly compared with the results of the present one because several previous studies which compared the effects of the DCF and ME on syntactic accuracy of the written texts explored the focused/selective type of the mentioned WCF types (see e.g., Bitchener, 2008; Bitchener \& Knoch, 2008, 2009, 2010a; Diab, 2015; Sheen, 2007; Shintani, Ellis, \& Suzuki, 2014; Stefanou \& Révész, 2015) 
The majority of the mentioned studies revealed that after receiving the WCF, the students' written accuracy improved significantly in the immediate and delayed post-tests, but the control group did not experience such improvement; further, no significant difference was found between the DCF and ME (Bitchener, 2008; Bitchener \& Knoch, 2008, 2009, 2010; Stefanou \& Révész, 2015). However, Sheen (2007) revealed that both direct metalinguistic and direct-only correction groups were significantly better than the control group on the immediate posttests, but the direct metalinguistic group outperformed "the direct-only correction group in the delayed posttests" (p. 255). On the contrary, Shintani et al., (2014), who compared the effects of the DCF and ME on university students' accuracy in terms of using indefinite article and the hypothetical conditional, found that only the accuracy of the hypothetical conditional increased. The DCF was more effective than the ME. The results also indicated that the DCF was more beneficial than $\mathrm{ME}$ with regard to errors relevant to complex syntactical structure.

Regarding the present study, it was found that the accuracy of students who received the WCF (i.e., DCF and ME) outperformed those in the control group both in the immediate and delayed post-test and no significant difference was found between the DCF and ME; thus, these found results can be similar to the ones found by Bitchener (2008), Bitchener and Knoch (2008, 2009, 2010), Stefanou and Révész (2015) as well as Benson and DeKeyser (2019) only in the way that these researchers also found that the WCF can enhance the accuracy of the students' written texts. However, the above-mentioned studies investigated the focused type of the DCF and ME, not the unfocused or comprehensive feedback, like the one conducted in this study.

Different cognitive and socio-cognitive theoretical bases can also be consulted to explain the results of the present study. First, both DCF and ME, in this study, showed positive results, which is in line with the noticing hypothesis (Schmidt, 1990, 2001) as conscious attention to linguistic form facilitates or even is a prerequisite for the development of interlanguage, so the CF, as a focus-on-form intervention, can support the SLA process (DeKeyser, 1994; Han, 2002). It can be stated that by increasing learners' awareness of certain linguistic features, the WCF could have enabled learners to pay attention and be aware of the gaps between their own interlanguage production and the foreign language input (Hulstijn \& Schmidt, 1994; Swain, 1991). Subsequently, these noticing operations could have prompted restructuring of learners' developing interlanguage grammar (Gass, 1997; Long, 1996). Moreover, when the WCF is provided, learners have enough time, and therefore cognitive resources, to compare their output with the received $\mathrm{CF}$, which raises the likelihood that learners notice gaps in their interlanguage (Polio et al., 1998; Sheen, 2010b). It can be concluded that in the present study, the WCF may have helped the learners notice and mentally process the information, and this might have contributed to improvement in written syntactic accuracy also in line with Gass and Mackey (2015).

The results of the current study are also consistent with McLaughlin's (1990) information processing model and
Anderson's (1993) ACT (Adaptive Control of Thought) model. These models incorporate the view that information can be processed in either a controlled or automatic manner; additionally, learning includes a shift from controlled (i.e., declarative knowledge) toward automatic processing (i.e., automatized procedural knowledge). As a result, it can be argued that intentional learning in this study by means of providing the $\mathrm{CF}$ could have played an important role in the controlled phase, and then through 'practice' or 'repeated activation' over time, the language use became automatized. This is also corroborated by several other scholars (see e.g., Bitchener \& Ferris, 2012; DeKeyser, 1997, 2001; Hulstijn, 1995; Schmidt, 1990, 1994, 1995; Swain, 1985; Swain \& Lapkin, 1995).

Furthermore, the findings can be supported by the interaction approach to SLA because it is now commonly accepted within the SLA literature that there is a strong connection between the oral or written interaction and learning (Bitchener \& Ferris, 2012; Gass \& Mackey, 2015; Mackey, 2012; Spada \& Lightbown, 2010). It can be explained that in the present study, learning occurred through the learner's exposure to language, production of language and feedback on that production. Socio-cultural theory of human mental processing, based on Vygotsky also assumes that all cognitive development, including language development, takes place as a result of social interactions, especially when learners can collaborate and interact with more knowledgeable speakers of the L2 (e.g., teachers) (Bitchener \& Ferris, 2012). Experts in this field suggested that L2 learners can reach higher levels of linguistic knowledge when they receive proper scaffolding; and learners, with the help of other regulation (e.g., provided by teachers) can finally be self-regulated (i.e., able to use the L2 autonomously) (Lantolf \& Thorne, 2007; Lantolf, Thorne, \& Poehner, 2015; Mackey, 2012). These other regulators may utilize various strategies; one of which is the CF (Lantolf \& Thorne, 2007). In short, the WCF types utilized in this study have served the purpose of the research well and the learners received proper scaffolding, so their written syntactic accuracy improved.

\section{PEDAGOGICAL IMPLICATIONS}

The main and foremost implication of the present findings is that both comprehensive DCF and ME are useful instruments to be employed to help learners improve their written syntactic accuracy. However, the participants in this study, who benefited from the unfocused WCF, were at upper-intermediate level of English proficiency. Bitchener and Ferris (2012) argued that the unfocused WCF would be more useful for the learners of upper-intermediate level of English proficiency. Additionally, as Ferris (2004), Hyland and Hyland (2006), as well as Sheen (2007) stated, the learners' educational level can affect the degree to which the learners benefit from the WCF, and the learners' educational level can be indicative of their level of metalinguistic awareness. That is why learners with lower levels of (meta) linguistic competence might be less able to correct their own errors based on the comprehensive WCF. Consequently, to employ the comprehensive feedback, teachers are suggested 
consider the learners' both educational and metalinguistic competence levels. Moreover, comprehensive WCF can be an effective technique in contexts where teachers need to focus on communicating content or improvement of the overall accuracy of their students' writing rather than on language as an object and learning one or a few specific linguistic feature(s) because the unfocused/comprehensive feedback is mainly concerned with the writing as a whole instead of the writing to practice grammar (Bruton, 2009b; Van Beuningen, 2010, 2011).

\section{SUGGESTIONS FOR FURTHER RESEARCH}

In this study, the participants' success in revising their texts was not measured. Especially because the ME group did not receive the exact correct form of their essays, it could be useful if the accuracy of the revisions were also measured. Therefore, future studies can include this factor. Furthermore, some critics may think a two-week interval for the posttest is less likely for comprehensive feedback to yield empirically robust findings in the long term and be pedagogically effective; thus, another study can be done with a longer interval to measure the retention of unfocused/comprehensive feedback over a longer period.

\section{REFERENCES}

Anderson, J. R. (1993). Rules of the mind. Hillsdale, NJ: Lawrence Erlbaum.

Benson, S., \& DeKeyser, R. (2019). Effects of written corrective feedback and language aptitude on verb tense accuracy. Language Teaching Research, 23(6), 702-726. https://doi.org/10.1177/1362168818770921

Bitchener, J. (2008). Evidence in support of written corrective feedback. Journal of Second Language Writing, 17(2), 102-118. https://doi.org/10.1016/j.jslw.2007.11.004

Bitchener, J., East, M., \& Cartner, H. (2010). The effectiveness of providing second language (L2) writers with on-line written corrective feedback. Ako Aotearoa. Ako Aotearoa Publication. Retrieved from https://akoaotearoa.ac.nz/download/ng/file/group-5/ the-effectiveness-of-providing-second-language-writers-with-on-line-written-corrective-feedback.pdf

Bitchener, J., \& Ferris, D. R. (2012). Written corrective feedback in second language acquisition and writing. New York, NY: Routledge.

Bitchener, J., \& Knoch, U. (2008). The value of written corrective feedback for migrant and international students. Language Teaching Research, 12(3), 409-431. https:// doi.org/10.1177/1362168808089924

Bitchener, J., \& Knoch, U. (2009). The relative effectiveness of different types of direct written corrective feedback. System, 37(2), 322-329. https://doi.org/10.1016/j.system.2008.12.006

Bitchener, J., \& Knoch, U. (2010a). Raising the linguistic accuracy level of advanced L2 writers with written corrective feedback. Journal of Second Language Writing, 19(4), 207-217. https://doi.org/10.1016/j. jslw.2010.10.002
Bitchener, J., \& Knoch, U. (2010b). The contribution of written corrective feedback to language development: A ten month investigation. Applied Linguistics, 31(2), 193-214. https://doi.org/10.1093/applin/amp016

Bitchener, J., Young, S., \& Cameron, D. (2005). The effect of different types of corrective feedback on ESL student writing. Journal of Second Language Writing, 14(3), 191-205. https://doi.org/10.1016/j.jslw.2005.08.001

Bonilla López, M., Van Steendam, E., Speelman, D., \& Buyse, K. (2018). The differential effects of comprehensive feedback forms in the second language writing class. Language Learning, 68(3), 813-850. https://doi. org/10.1111/lang.12295

Bruton, A. (2009a). Designing research into the effects of grammar correction in L2 writing: Not so straightforward. Journal of Second Language Writing, 18(2), 136140. https://doi.org/10.1016/j.jslw.2009.02.005

Bruton, A. (2009b). Improving accuracy is not the only reason for writing, and even if it were ... System, 37(4), 600-613. https://doi.org/10.1016/j.system.2009.09.005

Bruton, A. (2010). Another reply to Truscott on error correction: Improved situated designs over statistics. System, 38(3), 491-498. https://doi.org/10.1016/j.system.2010.07.001

Chandler, J. (2003). The efficacy of various kinds of error feedback for improvement in the accuracy and fluency of L2 student writing. Journal of Second Language Writing, 12(3), 267-296. https://doi.org/10.1016/S10603743(03)00038-9

DeKeyser, R. (2015). Skill acquisition theory. In B. VanPatten \& J. Williams (Eds.), Theories in second language acquisition: An introduction (2nd ed.), (pp. 94-112). New York, NY: Routledge.

DeKeyser, R. M. (1994). Implicit and explicit learning of second language grammar: A pilot study. TESOL Quarterly, 28(1), 188-194. https://doi.org/10.2307/3587210

DeKeyser, R. M. (1997). Beyond explicit rule learning: Automatizing second language morphosyntax. Studies in Second Language Acquisition, 19(02), 195-222. https:// doi.org/10.1017/S0272263197002040

DeKeyser, R. M. (2001). Automaticity and automatization. In P. Robinson (Ed.), Cognition and second language instruction (pp. 125-151). Cambridge, UK: Cambridge University Press.

Diab, N. M. (2015). Effectiveness of written corrective feedback: Does type of error and type of correction matter? Assessing Writing, 24, 16-34. https://doi.org/10.1016/j. asw.2015.02.001

Ellis, R. (2009). A typology of written corrective feedback types. English Language Teaching, 63(2), 97-107. https://doi.org/10.1093/elt/ccn023

Ellis, R., Sheen, Y., Murakami, M., \& Takashima, H. (2008). The effects of focused and unfocused written corrective feedback in an English as a foreign language context. System, 36(3), 353-371. https://doi.org/10.1016/j.system.2008.02.001

Ellis, R., \& Shintani, N. (2014). Exploring language pedagogy through second language acquisition research. New York, NY: Routledge. 
Ferris, D. R. (1999). The case for grammar correction in L2 writing classes, a response to Truscott (1996). Journal of Second Language Writing, 8(1), 1-11. https://doi. org/10.1016/S1060-3743(99)80110-6

Ferris, D. R. (2003). Response to student writing: Implications for second language students. Mahwah, NJ: Lawrence Erlbaum Associates.

Ferris, D. R. (2004). The "grammar correction" debate in L2 writing: Where are we, and where do we go from here? (and what do we do in the meantime ...?). Journal of Response to Writing, 13(1), 49-62. https://doi. org/10.1016/j.jslw.2004.04.005

Ferris, D. R. (2006). Does error feedback help student writers? New evidence on the short- and long-term effects of written error correction. In K. Hyland \& F. Hyland (Eds.), Feedback in second language writing: Contexts and issues (pp. 81-104). New York, NY: Cambridge University Press.

Ferris, D. R. (2010). Second language writing research and written corrective feedback in SLA: Intersections and practical applications. Studies in Second Language Acquisition, 32(02), 181-201. https://doi.org/10.1017/ S0272263109990490

Field, A. (2013). Discovering statistics using SPSS (4th. ed.). London: Sage.

Frear, D., \& Chiu, Y. H. (2015). The effect of focused and unfocused indirect written corrective feedback on EFL learners' accuracy in new pieces of writing. System, 53, 24-34. https://doi.org/10.1016/j.system.2015.06.006

Gass, S. M. (1997). Input, interaction and the development of second languages. Mahwah, NJ: Lawrence Erlbaum Associates.

Gass, S. M., \& Mackey, A. (2015). Input, interaction, and output in second language acquisition. In B. VanPatten \& J. Williams (Eds.), Theories in second language acquisition: An introduction (2nd ed.), (pp. 180-206). New York, NY: Routledge.

Gass, S. M., \& Varonis, E. (2004). Input, interaction and second language production. Studies in Second Language Acquisition, 16(3), 283-302. https://doi.org/10.1017/ S0272263100013097

Geranpayeh, A. (2003). A quick review of the English quick placement test. Extract from Research Notes, 12, 8-10. Retrieved from http://www.lingue.uniss.it/documenti/ lingue/what is the QPT.pdf

Guénette, D. (2007). Is feedback pedagogically correct? Research design issues in studies of feedback on writing. Journal of Second Language Writing, 16(1), 40-53. https://doi.org/10.1016/j.jslw.2007.01.001

Guénette, D. (2012). The pedagogy of error correction: Surviving the written corrective feedback challenge. TESL CANADA JOURNAL/REVUE TESL DU CANADA, 30(1), 117-126. https://doi.org/10.18806/tesl.v30i1.1129

Han,Z.H.(2002). Rethinking the role of corrective feedback in communicative language teaching. RELC Journal, 33(1), 1-34. https://doi.org/10.1177/003368820203300101

Hartshorn, K. J., Evans, N. W., Merrill, P. F., Sudweeks, R. R., Strong-Krause, D., \& Anderson, N. J. (2010). Effects of dynamic corrective feedback on ESL writing accuracy. TESOL Quarterly, 44(1), 84-109. https://doi. org/10.5054/tq.2010.213781

Havranek, G. (2002). When is corrective feedback most likely to succeed? International Journal of Educational Research, 37(3-4), 255-270. https://doi.org/10.1016/ S0883-0355(03)00004-1

Hulstijn, J. H. (1995). Not all grammar rules are equal: Giving grammar instruction its proper place in foreign language teaching. In R. Schmidt (Ed.), Attention and awareness in foreign language learning (pp. 359-386). Honolulu: University of Hawaii.

Hulstijn, J. H., \& Schmidt, R. (1994). Guest editors' introduction. AILA Review, 11, 5-10. Retrieved from http://www. aila.info/download/publications/review/AILA11.pdf

Hyland, K., \& Hyland, F. (2006). Interpersonal aspects of response: Constructing and interpreting teacher written feedback. In K. Hyland \& F. Hyland (Eds.), Feedback in second language writing: Contexts and issues (pp. 206-224). New York, NY: Cambridge University Press.

Karim, K., \& Nassaji, H. (2018). The revision and transfer effects of direct and indirect comprehensive corrective feedback on ESL students' writing. Language Teaching Research, 1-21. https://doi. org/10.1177/1362168818802469

Kepner, C. G. (1991). An experiment in the relationships of types of written feedback to the development of second languagewriting skills. Modern LanguageJournal, 75(3), 305-313. https://doi.org/10.1111/j.1540-4781.1991. tb05359.x

Lantolf, J. P., \& Thorne, S. L. (2007). Sociocultural theory. In B. VanPatten \& J. Williams (Eds.), Theories in second language acquisition: An introduction (pp. 201-224). Mahwah, NJ: Lawrence Erlbaum Associates.

Lantolf, J. P., Thorne, S. L., \& Poehner, M. E. (2015). Sociocultural theory and second language development. In B. VanPatten \& J. Williams (Eds.), Theories in second language acquisition: An introduction (pp. 207-226). New York, NY: Routledge.

Larson-Hall, J. (2010). A guide to doing statistics in second language research using SPSS. New York, NY: Routledge.

Lee, I. (2004). Error correction in L2 secondary writing classrooms: The case of Hong Kong. Journal of Second Language Writing, 13(4), 285-312. https://doi. org/10.1016/j.jslw.2004.08.001

Lee, I. (2008). Understanding teachers' written feedback practices in Hong Kong secondary classrooms. Journal of Second Language Writing, 17(2), 69-85. https://doi. org/10.1016/j.jslw.2007.10.001

Long, M. H. (1996). The role of the linguistic environment in second language acquisition. In W. C. Ritchie \& T. K. Bhatia (Eds.), Handbook of second language acquisition (pp. 438-468). San Diego, CA: Academic Press.

Lyster, R., Lightbown, P. M., \& Spada, N. (1999). A response to Truscott's 'What's wrong with oral grammar correction".' Canadian Modern Language Review, 55(4), 457-467. https://doi.org/10.3138/cmlr.55.4.457 
Mackey, A. (2012). Input, interaction, and corrective feedback in L2 learning. Oxford, UK: Oxford University Press.

Mackey, A., \& Gass, S. M. (2005). Second language research: Methodology and design. Mahwah, New Jersey: Lawrence Erlbaum Associates, Inc.

McLaughlin, B. (1990). "Conscious" versus "unconscious" learning. TESOL Quarterly, 24(4), 617-634. https://doi. org/10.2307/3587111

Pallant, J. (2013). SPSS survival manual: A step by step guide to data analysis using IBM SPSS (5th. ed.). Berkshire, England: Open University Press.

Phakiti, A. (2010). Analysing quantitative data. In B. Paltridge \& A. Phakiti (Eds.), Continuum companion to research methods in applied linguistics (pp. 39-49). New York, NY: Continuum Companions.

Polio, C., Fleck, C., \& Leder, N. (1998). "If only I had more time": ESL learners' changes in linguistic accuracy on essay revisions. Journal of Second Language Writing, 7(1), 43-68. https://doi.org/10.1016/S10603743(98)90005-4

Robb, T., Ross, S., \& Shortreed, I. (1986). Salience of feedback on error and its effect on EFL writing quality. TESOL Quarterly, 20(1), 83-93. https://doi.org/10.2307/3586390

Sachs, R., \& Polio, C. (2007). Learners' uses of two types of written feedback on a L2 writing revision task. Studies in Second Language Acquisition, 29(01), 67-100. https://doi.org/10.10170S0272263107070039

Schmidt, R. W. (1990). The role of consciousness in second language learning. Applied Linguistics, 11(2), 129-158. https://doi.org/10.1093/applin/11.2.129

Schmidt, R. (1993). Awareness and second language acquisition. Annual Review of Applied Linguistics, 13, 206226. https://doi.org/10.1017/S0267190500002476

Schmidt, R. (1994). Deconstructing consciousness in search of useful definitions for applied linguistics. Aila Review, 11, 11-26. Retrieved from http://www.aila.info/download/publications/review/AILA11.pdf

Schmidt, R. W. (1995). Consciousness and foreign language learning: A tutorial on the role of attention and awareness in learning. In R. W. Schmidt (Ed.), Attention and awareness in foreign language learning and teaching (pp. 1-63). Honolulu, HI: University of Honolulu.

Schmidt, R. W. (2001). Attention. In P. Robinson (Ed.), Cognition and second language instruction (pp. 3-32). Cambridge, UK: Cambridge University Press.

Semke, H. D. (1984). The effects of the red pen. Foreign Language Annals, 17(3), 195-202. https://doi. org/10.1111/j.1944-9720.1984.tb01727.x

Sheen, Y. (2007). The effect of focused written corrective feedback and language aptitude on ESL learners' acquisition of articles. TESOL Quarterly, 41(2), 255-283. https://doi.org/10.1002/j.1545-7249.2007.tb00059.x

Sheen, Y. (2010a). Differential effects of oral and written corrective feedback in the ESL classroom. Studies in Second Language Acquisition, 32(02), 203-234. https:// doi.org/10.1017/S0272263109990507

Sheen, Y. (2010b). Introduction: The role of oral and written corrective feedback in SLA. Studies in Second Language
Acquisition, 32(02), 169-179. https://doi.org/10.1017/ S0272263109990489

Sheen, Y., Wright, D., \& Moldawa, A. (2009). Differential effects of focused and unfocused written correction on the accurate use of grammatical forms by adult ESL learners. System, 37(4), 556-569. https://doi.org/10.1016/j. system.2009.09.002

Sheppard, K. (1992). Two feedback types: Do they make a difference? RELC Journal, 23(1), 285-304. https://doi. org/10.1177/003368829202300107

Shintani, N., \& Ellis, R. (2013). The comparative effect of direct written corrective feedback and metalinguistic explanation on learners' explicit and implicit knowledge of the English indefinite article. Journal of Second Language Writing, 22(3), 286-306. https://doi. org/10.1016/j.jslw.2013.03.011

Shintani, N., Ellis, R., \& Suzuki, W. (2014). Effects of written feedback and revision on learners' accuracy in using two English grammatical structures. Language Learning, 64(1), 103-131. https://doi.org/10.1111/lang.12029

Soltanpour, F., \& Valizadeh, M. (2018). Revision-mediated and attention-mediated feedback: Effects on EFL learners' written syntactic accuracy. Advances in Language and Literary Studies, 9(4), 83-91. https://doi. org/10.7575/aiac.alls.v.9n.4p.83

Spada, N., \& Lightbown, P. M. (2010). Second language acquisition. In N. Schmitt (Ed.), An introduction to applied linguistics (2nd ed.), (pp. 108-123). Abingdon, Oxon: Hodder Education.

Stefanou, C., \& Révész, A. (2015). Direct written corrective feedback, learner differences, and the acquisition of second language article use for generic and specific plural reference. Modern Language Journal, 99(2), 263-282. https://doi.org/10.1111/modl.12212

Storch, N. (2010). Critical feedback on written corrective feedback research. International Journal of English Studies, 10(2), 29-46. Retrieved from https://dialnet. unirioja.es/descarga/articulo/3424315.pdf

Swain, M. (1985). Communicative competence: Some roles of comprehensible input and comprehensible output in its development. In S. M. Gass \& C. G. Madden (Eds.), Input in second language acquisition (pp. 64-81). Cambridge, UK: Cambridge University Press.

Swain, M. (1991). French immersion and its offshoots: Getting two for one. In B. F. Freed (Ed.), Foreign language acquisition: Research and the classroom (pp. 91-103). Lexington, MA: Heath.

Swain, M. (1995). Three functions of output in second language learning. In G. Gook \& B. Seidlhofer (Eds.), Principle and practice in applied linguistics (pp. 125-144). Oxford: Oxford University Press.

Swain, M., \& Lapkin, S. (1995). Problems in output and the cognitive processes they generate: A step towards second language learning. Applied Linguistics, 16(3), 371391. https://doi.org/10.1093/applin/16.3.371

Truscott, J. (1996). The case against grammar correction in L2 writing classes. Language Learning, 46(2), 327-369. https://doi.org/10.1111/j.1467-1770.1996.tb01238.x 
Truscott, J. (1999). The case for "The case against grammar correction in L2 writing classes": A response to Ferris. Journal of Second Language Writing, 8(2), 111-122. https://doi.org/10.1016/S1060-3743(99)80124-6

Truscott, J. (2004). Evidence and conjecture on the effects of correction: A response to Chandler. Journal of Second Language Writing, 13(4), 337-343. https://doi. org/10.1016/j.jslw.2004.05.002

Truscott, J. (2007). The effect of error correction on learners' ability to write accurately. Journal of Second Language Writing, 16(4), 255-272. https://doi.org/10.1016/j. jslw.2007.06.003

Truscott, J. (2009). Arguments and appearances: A response to Chandler. Journal of Second Language Writing, 18(1), 59-60. https://doi.org/10.1016/j.jslw.2008.09.001

Truscott, J. (2010). Some thoughts on Anthony Bruton' s critique of the correction debate. System, 38(2), 329-335. https://doi.org/10.1016/j.system.2010.03.014

Truscott, J., \& Hsu, A. Y. (2008). Error correction, revision, and learning. Journal of Second Language Writing, 17(4), 292-305. https://doi.org/10.1016/j.jslw.2008.05.003
Van Beuningen, C. G. (2010). Corrective feedback in L2 writing: Theoretical perspectives, empirical insights, and future directions. International Journal of English Studies, 10(2), 1-27. Retrieved from http://revistas. um.es/ijes/article/view/119171

Van Beuningen, C. G. (2011). The effectiveness of comprehensive corrective feedback in second language writing. Oisterwijk: Boxpress.

Van Beuningen, C. G., De Jong, N. H., \& Kuiken, F. (2008). The effect of direct and indirect corrective feedback on L2 learners' written accuracy. ITL - International Journal of Applied Linguistics, 156, 279-296. https://doi. org/10.1075/itl.156.24beu

Van Beuningen, C. G., De Jong, N. H., \& Kuiken, F. (2012). Evidence on the effectiveness of comprehensive error correction in second language writing. Language Learning, 62(1), 1-41. https://doi.org/10.1111/j.1467-9922.2011.00674.x

VanPatten, B. (2015). Input processing in adult SLA. In B. VanPatten \& J. Williams (Eds.), Theories in second language acquisition: An introduction (2nd ed.), (pp. 113134). New York, NY: Routledge. 